\title{
Polyplacophora species richness, composition and distribution of its community associated with the intertidal rocky substrate in the marine priority region No. 32 in Guerrero, Mexico
}

\author{
Rafael Flores-Garza ${ }^{{ }^{*}}$, Lizeth Galeana-Rebolledo ${ }^{1}$, Adriana Reyes-Gómez ${ }^{1}$, \\ Sergio García Ibáñez ${ }^{1}$, Carmina Torreblanca-Ramírez ${ }^{2}$, \\ Pedro Flores-Rodríguez y Arcadio Valdés González ${ }^{1}$ \\ ${ }^{1}$ Unidad Académica de Ecología Marina, Laboratorio de Ecología Costera y Sustentabilidad, Fraccionamiento Las Playas, Acapulco, \\ Mexico; ${ }^{*}$ Corresponding Author: rfloresgarza@yahoo.com \\ ${ }^{2}$ Doctorado en Ciencias Ambientales, Unidad de Ciencias de Desarrollo Regional, Universidad Autónoma de Guerrero. Calle Pino \\ s/n Colonia El Roble Acapulco, Acapulco, Mexico.
}

Received 31 August 2012; revised 7 October 2012; accepted 14 October 2012

\section{ABSTRACT}

The coast of Acapulco is located within the Marine Priority Region No. 32 (MPR No. 32) at the State of Guerrero, Mexico. The National Commission for the Knowledge and Use of Biodiversity has stated the lack of information on marine species that live there, among which are the Class Polyplacophora. This study aimed to: 1) determine species richness, 2) the community structure based on the representative families, 3) estimate the density, 4) locate species distribution, 5) determine their degree of occurrence (hierarchical position) within the community, 6) analyze the structure of length and width across the populations and 7) estimate the diversity index. The intertidal rocky substrate at seven beaches was sampled from 2009 to 2012 . The sampling unit $1 \mathrm{~m}^{2}$, while the area sampled was $10 \mathrm{~m}^{2}$. It was analyzed 2.548 specimens of Polyplacophora, with 20 species identified. Tonicellidae and Ischnochitonidae were the Families better represented inspecies richness and Chitonidae in abundance. Lepidochitona flectens is a new record for the Mexican Tropical Pacific and Stenoplax mariposa for MPR. No. 32. The density was 25.48 specimens $/ \mathrm{m}^{2}$. Eight dominant species were determined. Chiton albolineatus had the highest density. Ischnochiton muscarius, Chaetopleura unilineata, Chiton albolineatus and Chiton articulatus presented wide distribution. Chiton articulatus showed the largest size in length and width. H' $=2.01$ bits/individual. Numerous dominant species were pre- sent with broad and regular distribution, probably due to Polyplacophora body design, which allows for better adaptation to the rigorous environmental conditions of the rocky intertidal.

Keywords: Polyplacophora; Species Richness; Distribution; Sizes

\section{INTRODUCTION}

The National Commission for Knowledge and Use of Biodiversity in spanish: Comisión Nacional para el Conocimiento y Uso de la Biodiversidad (CONABIO) stated the existence of 70 marine priority regions for the conservation of Mexico's biodiversity on coastal and ocean regions. On the coast of Guerrero, there are located four Marine Priority Regions (MPR) which denoted the lack of information about marine species that inhabit these regions. Marine Priority Region No. 32 (MPR No. 32) is one of the regions that are located on the coast of Guerrero and according to CONABIO, one of the major issues is the lack of knowledge in the conservation and diversity of the zone [1].

An important part of the marine fauna on the MPR No. 32 are the Polyplacophora or chitons, mollusks whose shell is composed of eight valves hinged to each other, most of these are herbivores, that inhabit rocky substrates, including the intertidal zone, but also known from deepwater [2].

Despite their diversity and abundance, chitons are usually underestimated in mollusks faunal studies conducted in Mexico, except for Chiton (Chiton) articulatus (Sowerby, 1832) due to its commercial importance has been the species that is largely studied [3-7], there is 
widespread ignorance about the species component of this Class. This lack of knowledge is not only present at marine priority regions of the State of Guerrero, but covers most of the Mexican Pacific. This may be due to several factors, such as the absence of commercially important species, the cryptic habits of most species and mainly, the difficulties of collecting in the harsh waves pounding areas on the surf zone at rocky shores, where chitons are abundant [8]. There are reports in the literature of Polyplacophora with taxonomic scope and geographical distribution made in the Mexican Pacific, such as [9-12] and those made in the Mexican coast by $[6,8,13-20]$. With respect to marine priority regions on the coast of Guerrero, the information is based on reports mostly made in communities where Polyplacophora mollusks are part of all the classes analyzed [21-26].

The objectives were to improve the information on marine fauna from the MPR No. 32 and specifically on: 1) know species richness, 2) The community structure of Polyplacophora based on the representative families, with two criteria: a) species richness and b) abundance, 3) density, 4) species distribution, 5) occurrence of species by hierarchical position within the community, 6) size by length and width across the populations that constitute the community and 7) estimate their diversity by Shannon-Wiener $\left(\mathrm{H}^{\prime}\right)$ and the index of uniformity or equity of Pielou (J').

\section{FIELD METHODOLOGY}

\subsection{Study Area}

The MPR No. 32 (Coyuca-Tres Palos area) is located at latitude $16^{\circ} 35^{\prime} 24^{\prime \prime}$ to $17^{\circ} 28^{\prime} 12^{\prime \prime}$ and longitude $99^{\circ} 25^{\prime} 12^{\prime \prime}$ to $100^{\circ} 33^{\prime}$ (Figure 1).

The climate is warm sub-humid, presents an average annual temperature over $26^{\circ} \mathrm{C}$, tropical storms and hurricanes occur from May to November. Belongs to the North American plate, is constituted by metamorphic rocks and a narrow platform. It is bathed by Costa Rica Coastal and North Equatorial Currents, receives freshwater input from rivers, some areas are hit by harsh high surf waves, el Niño, red tide and other processes of turbulence occurs. It is an area with a rich and abundant biodiversity: mollusks, polychaetes, echinoderms, crustaceans, turtles, fish, birds, marine mammals, endemic fish and mangrove, and is an important bird feeding area. There are also regulatory issues; ignorance of current regulations for the use of resources and illegal fishing is frequent. This region has particular importance since represents an area for several zoological groups with respect to conservation, especially birds and their diversified habitat, and the potential impact by tourism and the lack of information on this issue [1]. Acapulco is located in the RMP No. 32, has a coastline of $62 \mathrm{~km}$. and almost the entire intertidal zone is constituted of bedrock.

\subsection{Fieldwork}

Sampling was conducted from 2009 to 2012 at seven sites: Parque de la Reina, Tlacopanocha, Majahua, Muelle, Manzanillo, La Angosta and Pie de la Cuesta. Geographical coordinates was registered for each site and described according to the following criteria: approximate length of the sampling area, the substrate structure and stability, rock type, and wave exposure of the substrate. Descriptions of the collection sites were based on [27], geological maps of the National Institute of Statistics, Geography and Informatics "Instituto Nacional de Estadística, Geografía e Informática" INEGI (Acapulco maps E14-11, 1:50,000), and complemented with field observations (Table 1).

The sites may change with the type of substrate, its stability and exposure to wave impact; and were classified as Type of substrate: a) Rock masses: fixed structures such as walls, cliffs, terraces, and alike. b) Large boulders: unattached rocks larger than $50 \mathrm{~cm}$, immovable or difficult to move by the wave' simpact. c) Rolled boulders: loose rock smaller than 50 and greater than 8 $\mathrm{cm}$. that can easily be moved by the impact of the waves. d) Gravel: loose rocks o pebbles no larger than $8 \mathrm{~cm}$. The substrate stability was classified as: a) high: when the substrate remains practically unchanged by the impact of waves, b) middle: when basically does not change the configuration of the substrate by the waves impact but there is some rock displacement, c) low: when the site configuration changes by the impact of waves, most of rocks are moved. Wave exposure was classified as: a) High: when waves hits the substrate directly, unprotected, b) Middle: when the wave impact on the substrate is softened or hampered by barriers and c) Low: when the wave does not hit directly, since the sites are protected by different types of barriers.

Sampling was conducted on new moon, in the months of low rainfall and drought, where the tide is shallow and allows collecting on the intertidal zone. For the quantification of the organisms, a sampling area of $10 \mathrm{~m}^{2}$ was established. The sampling unit was $1 \mathrm{~m}^{2} 1 / 2$ inch vinyl polychloro frame, randomly selected the starting point where the frame was placed parallel to the coast, by setting the place with a rope of $30 \mathrm{mts}$ length, to provide continuity and representation of the area. All specimens of Polyplacophora found alive within the sampling unit were collected. Completed the collection of the first sampling unit, a two meters transect down the rope was allowed, and then again the vinyl polychloro frame was placed. This system was repeated until the $10 \mathrm{~m}^{2}$ total was sampled on each time. The specimens collected were preserved with 96\% ethyl alcohol and labeled. The jars with specimens were transferred to the laboratory to be identified and quantified for further work. 


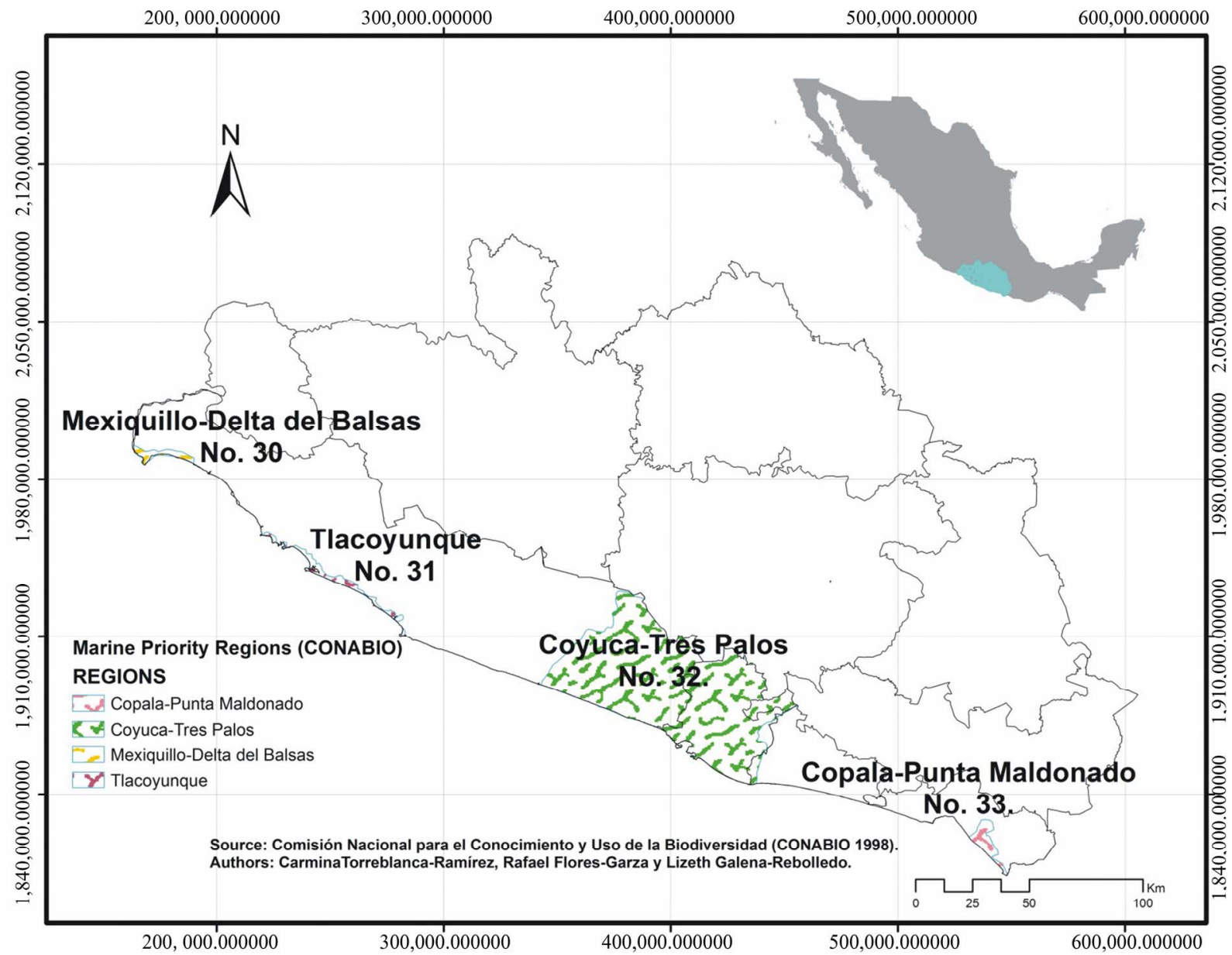

Figure 1. Illustration of the Marine Priority Regions, including No. 32, at the State of Guerrero, Mexico, which includes the study area.

Table1. Sampling sites considered in the study, indicating the location and relevant characteristics of the habitat.

\begin{tabular}{|c|c|c|c|c|c|c|c|c|}
\hline & \multirow{2}{*}{ Site } & \multicolumn{2}{|c|}{ Coordinates } & \multirow{2}{*}{$\begin{array}{l}\text { Length } \\
\text { of the Site }\end{array}$} & \multirow{2}{*}{$\begin{array}{c}\text { Type of } \\
\text { Substrate }\end{array}$} & \multirow{2}{*}{$\begin{array}{l}\text { Type of } \\
\text { Rock }\end{array}$} & \multirow{2}{*}{$\begin{array}{l}\text { Substrate } \\
\text { Stability }\end{array}$} & \multirow{2}{*}{$\begin{array}{c}\text { Wave } \\
\text { Exposure }\end{array}$} \\
\hline & & Latitud N & Longitud W & & & & & \\
\hline 1 & $\begin{array}{l}\text { Parque de } \\
\text { la Reina }\end{array}$ & $16^{\circ} 50^{\prime} 58.27^{\prime \prime}$ & $99^{\circ} 54^{\prime} 01.85^{\prime \prime}$ & 66.74 metros & $\begin{array}{c}\text { Rolled boulders and } \\
\text { gravel }\end{array}$ & $\begin{array}{c}\text { Artificial substrate } \\
\text { (construction rubble)and } \\
\text { igneous rocks }\end{array}$ & Low & Middle \\
\hline 2 & Tlacopanocha & $16^{\circ} 50^{\prime} 41.53^{\prime \prime}$ & $99^{\circ} 54^{\prime} 25.02^{\prime \prime}$ & 200 metros & $\begin{array}{c}\text { Large boulders and } \\
\text { gravel }\end{array}$ & $\begin{array}{c}\text { Artificial substrate } \\
\text { (construction rubble)and } \\
\text { igneous rocks }\end{array}$ & Media & Middle \\
\hline 3 & Majahua & $16^{\circ} 50^{\prime} 58.27^{\prime \prime}$ & $99^{\circ} 54^{\prime} 01.85^{\prime \prime}$ & 600 metros & $\begin{array}{c}\text { Large boulders and } \\
\text { rolled } \\
\text { boulders }\end{array}$ & Metamorphic & High & Low \\
\hline 4 & Muelle & $16^{\circ} 50^{\prime} 56.86^{\prime \prime}$ & $99^{\circ} 54^{\prime} 02.39^{\prime \prime}$ & 60 metros & $\begin{array}{l}\text { Large boulders and } \\
\text { rolled boulders }\end{array}$ & $\begin{array}{l}\text { Metamorphic rocks and } \\
\text { artificial substrate } \\
\text { (construction rubble) }\end{array}$ & Media & Middle \\
\hline 6 & La Angosta & $16^{\circ} 60^{\prime} 29.86^{\prime \prime}$ & $99^{\circ} 54^{\prime} 55.70^{\prime \prime}$ & 48.14 metros & $\begin{array}{l}\text { Rock masses and } \\
\text { rolled boulders }\end{array}$ & Metamorphic rocks & High & High \\
\hline 7 & $\begin{array}{l}\text { Pie de la } \\
\text { Cuesta }\end{array}$ & $16^{\circ} 52^{\prime} 25.64^{\prime \prime}$ & $99^{\circ} 56^{\prime} 34.64^{\prime \prime}$ & 66 metros & $\begin{array}{l}\text { Rock masses and } \\
\text { rolled boulders }\end{array}$ & Metamorphic rocks & High & High \\
\hline
\end{tabular}




\subsection{Laboratory Work and Analysis}

Species identification was based on [10-12] and for systematic classification on [28]. The specimens collected were counted, identified, length and width measured $(\mathrm{mm})$ and subsequently registered at the Mollusk Collection on the Academic Unit of Marine Ecology at the Autonomous University of Guerrero ("Colección de Moluscos de la Unidad Académica de Ecología Marina de la Universidad Autónoma de Guerrero") and also deposited in the National Collection of Mollusks in the Malacology Laboratory, National Institute of Biology, of the National Autonomous University of Mexico ("Colección Nacional de Moluscos en el Laboratorio de Malacología del Instituto Nacional de Biología, Universidad Nacional Autónoma de México").

Richness was measured based on the number of species found per sample. The community structure was analyzed using the representation of families, which was evaluated based on species richness (amount of species per family) and abundance of organisms per family and expressed in percentage. The density is measured by estimating the average amount of specimens per $\mathrm{m}^{2}$. Species distribution of Polyplacophora, was interpreted as criterion on the percentage of sites at which a species was present (frequency of occurrence) and graded as follows: a) Wide distribution when the species is present at least in six sites, b) Regular distribution when the species was collected in four or five sites, c) Limited distribution when the species is found in two or three places and d) Irregular distribution when the species was only found in one place. Occurrence of the species (hierarchical position) within the community, was determined using the method of Olmstead-Tukey correlation, represented by the quadrant graphs [29], which was based on two estimators, one was the average of relative abundance of all species expressed in the logarithm of abundance +1 , and two, the average frequency of occurrence (expressed in percentage) of all the species represented in the sample. The percentage of frequency graphically analyzed the occurrence of each species (x axis) against the averaged percentage of relative abundance of each species, expressed in log abundance +1 (y axis). The dominant species were those whose values of abundance and frequency of occurrence exceeded the average of both estimates. Constant species were those whose abundance value, did not exceed the average value of the total abundance, but exceeded the average estimate for the frequency of occurrence. Numerous little frequent species were characterized by having their abundance value higher than the estimated average value for the abundance and frequency of occurrence value did not exceed the estimated average value for this variable. The occasional species were those that their value of abundance and frequency of occurrence did not exceed the arithmetic mean of estimated frequency of occurrence and abundance. The analysis of sizes and structure of the populations of chitons, was performed by measuring the length and width expressed in millimeters and obtaining the values of descriptive statistics such as maximum, minimum, mean and standard deviation. To measure the length of the chitons was performed from girdle from the anterior cephalic plate, to the posterior region in the anal plate, the width is measured from side to side of the girdle between the fourth and fifth plate [19]. For these purpose a digital caliper Vernier type (precision $0.01 \mathrm{~mm}$ ) was used. The diversity was assessed by the ShannonWiener index ( $\left.\mathrm{H}^{\prime}\right)$ and the index of uniformity or equity of Pielou (J').

\section{RESULTS}

2548 Polyplacophora specimens were sampled in the MPR No. 32. Twenty species from 10 genera and six families were identified. The best represented families in terms of species richness were Tonicellidae with one genus and six species, followed by Ischnochitonidae with three genera and five species. The best represented family on richness was Chitonidae with $70.95 \%$ of the collected specimens, and the least abundant was Acanthochitonidae with $0.11 \%$ (Table 2). On the inventoried analysis, two species were identified as new record for the MPR No. 32: The first of them, Lepidochitona (Dentrochiton) flectens (Carpenter, 1864) which inhabits at the rock masses and boulders, with metamorphic type of rock, and high wave exposure. The material analyzed is of one specimen, which measured $8.95 \mathrm{~mm}$ long and 5.5 $\mathrm{mm}$ wide. The second species as a new record, was Stenoplax (Stenoplax) mariposa (Bartsch MS, Dall, 1919); the habitat for this was pebbles and gravel, the substrate of artificial type represented by construction rubble and debris characterized by concrete remains of floors and columns, mixed with igneous rock, and with middle wave exposure. The specimen measured $7.65 \mathrm{~mm}$ and 5.55 $\mathrm{mm}$ wide. For the whole region it was estimated a density of 25.48 specimens per $\mathrm{m}^{2}$. Parque la Reina was the site with highest density, 66.9 specimens per $\mathrm{m}^{2}$, and the lowest one happened at Manzanillo with 4.5 specimens per $\mathrm{m}^{2}$. The species that showed the highest density was Chiton (Chiton) albolineatus Broderip \& Sowerby, 1829, followed by Ischnochiton (Ischnochiton) muscarius (Reeve, 1847) (Table 2).

With respect to geographical distribution in the MPR No. 32, species of wide distribution were I. muscarius, Chaetopleura (Chaetopleura) unilineata Leloup, 1954, C. articulatus and $C$. albolineatus found in six of the seven sites sampled, five species were found with regular distribution, eight species were of limited distribution and three species with irregular distribution (Table 3, Figure 2). 
Table 2. Species richness, relative abundance per family, density by species and descriptive statistics across Polyplacophora in the Marine Priority Region No. 32, at Guerrero, Mexico.

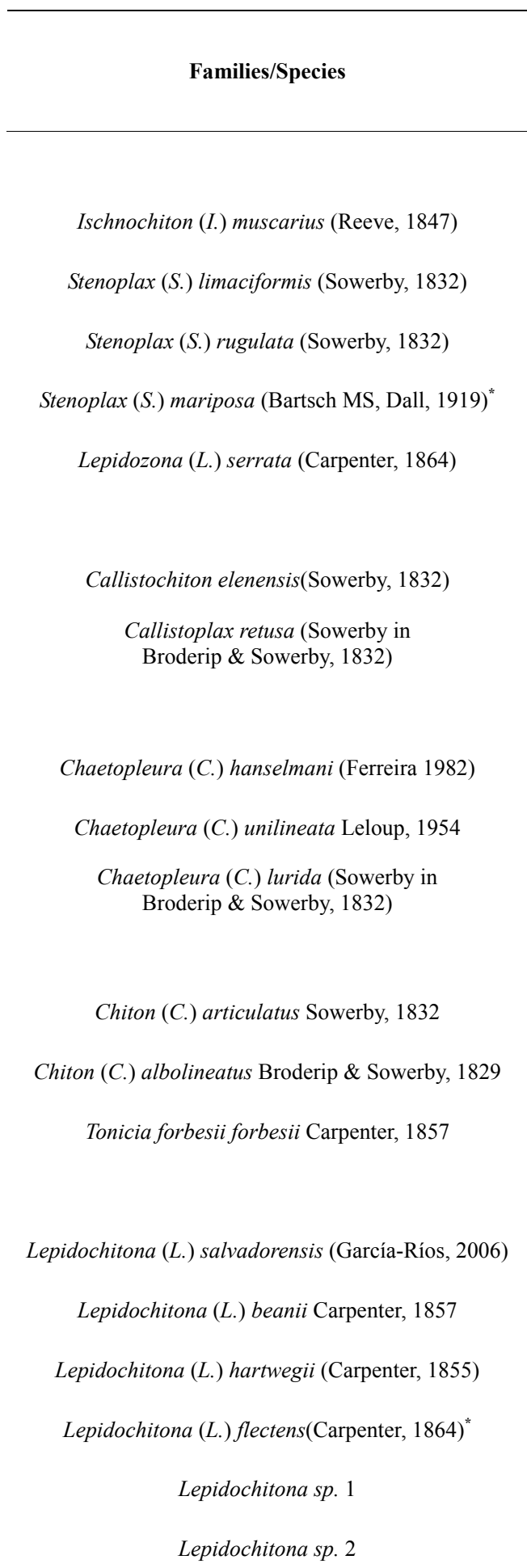

\begin{tabular}{lllllllll} 
A/F & \multicolumn{3}{c}{ Length $(\mathrm{mm})$} & \multicolumn{4}{c}{ Width $(\mathrm{mm})$} \\
\cline { 2 - 7 } & Men & Máx & Med & S.D. & Mín & Máx & Med & S.D.
\end{tabular}

\section{Ischnochitonidae}

\begin{tabular}{|c|c|c|c|c|c|c|c|c|c|}
\hline & 2.78 & 3.57 & 27.71 & 14.42 & 5.18 & 2.60 & 15.86 & 8.99 & 3.13 \\
\hline & 0.56 & 4.25 & 2.54 & 14.91 & 6.69 & 2.04 & 10.26 & 5.11 & 1.85 \\
\hline \multirow[t]{3}{*}{$14.36 \%$} & 0.04 & 5.33 & 6.13 & 5.73 & 0.56 & 2.76 & 3.63 & 3.19 & 0.61 \\
\hline & 0.01 & 7.65 & 7.65 & & & 5.55 & 5.55 & & \\
\hline & 0.27 & 4.96 & 10.17 & 6.43 & 1.78 & 2.96 & 3.99 & 3.66 & 0.47 \\
\hline
\end{tabular}

\section{Callistoplacidae}

$\begin{array}{llllllllll} & 0.2 & 4.39 & 11.66 & 7.50 & 1.76 & 2.44 & 5.70 & 4.14 & 1.10 \\ 3.53 \% & & & & & & & & & \\ & 0.7 & 4.55 & 24.07 & 13.62 & 4.98 & 2.37 & 9.00 & 5.64 & 1.40\end{array}$

\section{Chaetopleuridae}

$\begin{array}{rrrrrrrrrr} & 0.04 & 3.17 & 31.84 & 19.30 & 9.96 & 2.31 & 2.95 & 2.63 & 0.45 \\ 9.85 \% & 0.51 & 5.60 & 23.59 & 11.44 & 5.19 & 3.81 & 14.44 & 8.31 & 4.05 \\ & 1.96 & 5.11 & 30.97 & 18.43 & 4.66 & 4.37 & 17.98 & 11.13 & 2.87\end{array}$

Chitonidae

$\begin{array}{rrrrrrrrrr} & 1.89 & 6.09 & 50.74 & 22.83 & 9.39 & 3.69 & 28.70 & 13.76 & 5.58 \\ 70.95 \% & 16.01 & 3.18 & 33.61 & 17.56 & 7.00 & 2.09 & 14.46 & 12.56 & 6.15 \\ & 0.18 & 6.32 & 39.58 & 19.35 & 6.02 & 8.56 & 19.79 & 13.99 & 3.61\end{array}$

\section{Tonicellidae}

\begin{tabular}{|c|c|c|c|c|c|c|c|c|c|}
\hline & 0.12 & 6.01 & 13.77 & 9.39 & 2.65 & 3.96 & 6.43 & 5.08 & 0.97 \\
\hline & 0.05 & 6.12 & 6.28 & 6.20 & 0.11 & 3.01 & 3.77 & 3.39 & 0.53 \\
\hline & 0.01 & 4.50 & 4.50 & & & 2.77 & 2.77 & & \\
\hline & 0.01 & 8.95 & 8.95 & & & 5.05 & 5.05 & & \\
\hline & 0.07 & 6.50 & 24.07 & 14.16 & 4.51 & 2.79 & 5.53 & 4.06 & 0.99 \\
\hline & 0.04 & 3.43 & 8.46 & 5.27 & 2.21 & 2.22 & 4.25 & 3.81 & 0.89 \\
\hline
\end{tabular}

Acanthochitonidae

$\begin{array}{llllllllll}0.11 \% & 0.03 & 6.12 & 8.37 & 6.95 & 1.02 & 3.78 & 6.12 & 4.95 & 1.65\end{array}$ 
Table 3. Distribution type by frequency of occurrence of species of Polyplacophora in the Marine Priority Region No. 32 Guerrero, Mexico.

\begin{tabular}{|c|c|c|c|c|c|c|c|c|c|}
\hline \multicolumn{10}{|c|}{ Collecting Sites } \\
\hline Species & $\mathbf{A}$ & B & C & D & $\mathbf{E}$ & $\mathbf{F}$ & $\mathbf{G}$ & $\begin{array}{c}\text { Type of } \\
\text { Distribution }\end{array}$ & $\begin{array}{c}\text { Degree of } \\
\text { Appearance }\end{array}$ \\
\hline I. muscarius & $\mathrm{X}$ & $\mathrm{X}$ & $\mathrm{X}$ & $\mathrm{X}$ & $\mathrm{X}$ & $\mathrm{X}$ & & Wide & Dominant \\
\hline S. limaciformis & $\mathrm{X}$ & $\mathrm{X}$ & $\mathrm{X}$ & $\mathrm{X}$ & $\mathrm{X}$ & & & Regular & Dominant \\
\hline S. rugulata & $\mathrm{X}$ & & $\mathrm{X}$ & & $\mathrm{X}$ & & & Limited & Occasional \\
\hline S. mariposa & & & & & $\mathrm{X}$ & & & Irregular & Occasional \\
\hline L. serrata & $\mathrm{X}$ & $\mathrm{X}$ & $\mathrm{X}$ & & & & & Limited & Constant \\
\hline C. elenensis & $\mathrm{X}$ & $\mathrm{X}$ & & $\mathrm{X}$ & $\mathrm{X}$ & & & Regular & Dominant \\
\hline C. retusa & $\mathrm{X}$ & $\mathrm{X}$ & $\mathrm{X}$ & & $\mathrm{X}$ & $\mathrm{X}$ & & Regular & Dominant \\
\hline C. hanselmani & & $\mathrm{X}$ & $\mathrm{X}$ & & & & & Limited & Occasional \\
\hline C. unilineata & $\mathrm{X}$ & $\mathrm{X}$ & $\mathrm{X}$ & $\mathrm{X}$ & $\mathrm{X}$ & & $\mathrm{X}$ & Wide & Dominant \\
\hline C. lurida & $X$ & $X$ & $\mathrm{X}$ & $X$ & $\mathrm{X}$ & & & Regular & Dominant \\
\hline C. articulatus & $\mathrm{X}$ & $\mathrm{X}$ & $\mathrm{X}$ & & $\mathrm{X}$ & $\mathrm{X}$ & $\mathrm{X}$ & Wide & Dominant \\
\hline C. albolineatus & $\mathrm{X}$ & $\mathrm{X}$ & $\mathrm{X}$ & $\mathrm{X}$ & $\mathrm{X}$ & $\mathrm{X}$ & & Wide & Dominant \\
\hline T. forbesii forbesii & $\mathrm{X}$ & $\mathrm{X}$ & $\mathrm{X}$ & $\mathrm{X}$ & & & & Regular & NPF \\
\hline L. salvadorensis & & $\mathrm{X}$ & $\mathrm{X}$ & & & & & Limited & Occasional \\
\hline L. beanii & $X$ & $\mathrm{X}$ & $\mathrm{X}$ & & & & & Limited & Occasional \\
\hline$L$ hartwegii & & & $\mathrm{X}$ & & & & & Irregular & Occasional \\
\hline L. flectens & & & & & & & $\mathrm{X}$ & Irregular & Occasional \\
\hline Lepidochitona sp. 1 & & $\mathrm{X}$ & $\mathrm{X}$ & & & & & Limited & Occasional \\
\hline Lepidochitona sp. 2 & $\mathrm{X}$ & & $\mathrm{X}$ & & $\mathrm{X}$ & & & Limited & Occasional \\
\hline A. arragonites & $\mathrm{X}$ & & $\mathrm{X}$ & & $\mathrm{X}$ & & & Limited & Occasional \\
\hline Density of specimens $/ \mathrm{m}^{2}$ & 21.2 & 66.9 & 9.5 & 19.9 & 4.5 & 27.9 & 7.9 & & \\
\hline
\end{tabular}

A: Tlacopanocha; B: Parque de la Reina; C: Majahua; D: Manzanillo; E: Parque de la Reina Muelle; F: La Angosta; G: Pie de la Cuesta; X = Presenceat the site.

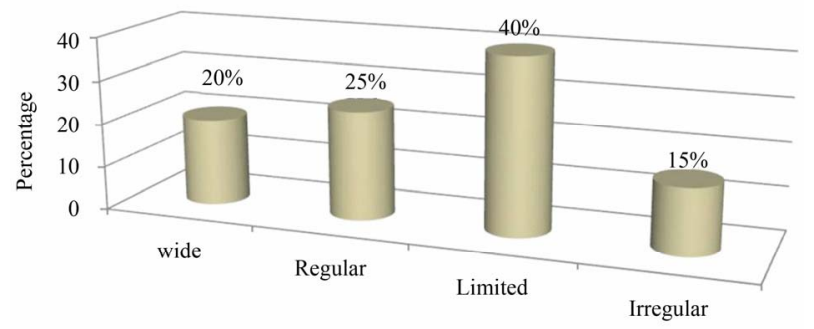

Species Distribution of Polyplacophora

Figure 2. Distribution type by frequency of occurrence of species of Polyplacophora in the Marine Priority Region No. 32 Guerrero, Mexico.

The degree of occurrence of the species (hierarchical position) in the community, found that eight were dominant, one was constant, one was numerous little frecuent and 10 were casual (Table 3, Figure 3).

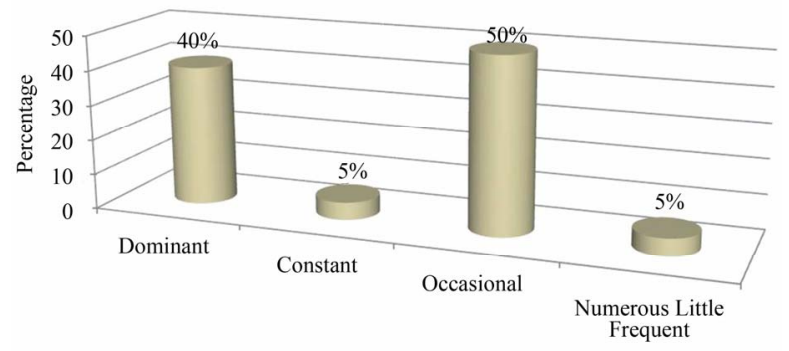

Degree of occurrence

Figure 3. Polyplacophora degree of occurrence by hierarchical position in the Marine Priority Region No. 32 of Guerrero, Mexico.

The largest species was $C$. articulatus with $50.74 \mathrm{~mm}$ $($ minimum $=6.9$, mean $=22.83$ and standard deviation $=$ $9.39 \mathrm{~mm})$ and the smallest one was Chaetopleura (Chaetopleura) hanselmani (Ferreira, 1982) measured 
$3.17 \mathrm{~mm}$ and $($ maximum $=31.84 \mathrm{~mm}$, mean $=19.30 \mathrm{~mm}$ and standard deviation $=9.96$ ). The species with largest width was $C$. articulatus, with $28.77 \mathrm{~mm}$ (minimum = $3.69 \mathrm{~mm}$, mean $=13.76 \mathrm{~mm}$ and standard deviation $=$ 5.58) and Stenoplax (Stenoplax) limaciformis (Sowerby, 1832) showed the lowest height which was of $2.04 \mathrm{~mm}$ (maximum $=10.26 \mathrm{~mm}$, mean $=5.11 \mathrm{~mm}$ and standard deviation $=1.85)$ (Table 2$)$.

The diversity index value of Shannon-Wiener (H') calculated for the MPR No. 32 was H'=2.01 bits/individual, while the value of uniformity or equity index of Pielou (J') was J' $=0.45$

\section{DISCUSSION}

\subsection{Species Richness}

We found agreement with the reports made to the Mexican Pacific shores where have analyzed the Class Polyplacophora [6,13-22,24,30], have found in the MPR 32 to the following species: I. muscarius; S. limaciformis; S. mariposa; Stenoplax (Stenoplax) rugulata (Sowerby, 1832); Lepidozona (Lepidozona) serrata (Carpenter, 1864); Callistochiton elenensis (Sowerby, 1832); Callistoplax retusa (Sowerby in Broderip \& Sowerby, 1832); Chaetopleura (Chaetopleura) lurida (Sowerby in Broderip \& Sowerby, 1832), C. hanselmani, T. forbesii forbesii Carpenter, 1857; C. albolineatus, C. articulatus; Lepidochitona (Lepidochitona) salvadorensis (García-Ríos, 2006); Lepidochitona sp.; Lepidochitona (Lepidochitona) beanii Carpenter, 1857 and Acanthochitona arragonites (Carpenter, 1857). And species reported by them and not found in the MPR No. 32 were: Ischnochiton sp. Ischnochiton (Ischnochiton) tridentatus Pilsbry, 1893; Stenoplax (Stenoplax) corruguta (Carpenter in Pilsbry, 1892); Lepidozona (Lepidozona) clathrata (Reeve, 1847); Lepidozona (Lepidozona) clarionensis Ferreira, 1983; Lepidozona (Lepidozona) rothi Ferreira, 1983; Callistochiton infortunatus Pilsbry, 1893; Callistochiton sp. Chiton (Chiton) virgulatus Sowerby, 1840; Chiton (Chiton) stokesii Sowerby, 1832; Chaetopleura mixta Dall, 1919; Chaetopleura scabricula (Sowerby, 1832); Nuttallina crossata (Berry, 1956); Acanthochitona avicula Carpenter, 1864; Acanthochitona exquisite Pilsbry, 1893 and Lepidochitona (Lepidochitona) keepiana Berry, 1948.

Previous reports on the MPR No. 32, which discusses the Class Polyplacophora were those of [21,23,25,26,32, $33]$ and were in agreement with the following species: $I$. muscarius, S. limaciformis; S. rugulata, L. serrata, C. elenensis, C. retusa; Chaetopleura (Chaetopleura) unilineata Leloup, 1954; C. hanselmani, C. lurida, C. articulatus, C. albolineatus, T. forbesii forbesii; Lepidochitona sp. 1; Lepidochitona sp. 2; L. salvadorensis, L. beanii, L. hartwegii and A. aragonites; and their reported species not found in our work were Radsiella triden- tata Pilsbry, 1893 and Stenoplax conspicua sonorana Berry, 1956.

Species richness of Polyplacophora found for the MPR No. 32 on this research was higher than that reported for other sites in the state of Guerrero and the Mexican Tropical Pacific, and corresponds to that expected in a tropical zone characterized by slight variations in temperature, complex bedrock that varies greatly from gravel to large blocks, creating different habitat spaces where many organisms can live in.

In the samples analyzed L. flectens was identified, which is a new to the coast of Guerrero and first time record for the Mexican Tropical Pacific; Its known distribution is along the west coast of North America, between latitudes $53^{\circ} \mathrm{N}$ (Hot Springs Island, off Queen Chalotte Island, British Columbia and $30^{\circ} \mathrm{N}$ (San Geronimo Island of the Baja California, Mexico); its distributional depth goes from the intertidal zone to $38 \mathrm{~m}$ deep [10]. The new location where found was in Pie de la Cuesta (16 52'25.64" N latitude and 9956'34.64" W longitude). Also recorded for the first time in the MPR No. 32 was $S$. mariposa, its distribution reported was at the low intertidal zone. Previously reported from subtidal and shallow shores, as in many locations along the Pacific coast of Baja California, as at Punto Malarritmo, Sebastian Vizcaino Bay to San Felipe in the Gulf of California and southward to along the coast of Mexico, recorded on Cholla Bay, Sonora, Cabo Corrientes, Jalisco, Revillagigedo Islands, Colima and coral reefs of Oaxaca $[8,9,11,20,34,35]$. The new location was at Parque La Reina (16 $50^{\prime} 58.27^{\prime \prime} \mathrm{N}$ latitude and $99^{\circ} 54^{\prime} 01.85^{\prime \prime} \mathrm{W}$ longitude).

One reason to have a thorough knowledge of the distribution of species is that it allows the precise determination of suitable habitat for each of them. It is important getting to know the habitat requirements and availability for species in a region, since makes it possible to assess the population status of the species in the spatial and temporal context. Also a precise knowledge of the distribution of species facilitates the identification of priority areas for conservation. Moreover, the inventory may provide more arguments to justify the conservation of important areas for conservation or reserves [36].

\subsection{Community Composition Based on the Representation of Families}

In previous reports such as [21-24] mentioned that the Chitonidae family as the one with best represented in number of species and abundance. Regarding species richness [25] listed Ischnochitonidae; and Tonicellidae was mentioned by [26] as best represented. This study also found Chitonidae as best represented family in abundance; and agreed with [26] in which the family Tonicellidae proved to be best represented in terms of 
species richness. Chitonidae and Tonicellidae therefore are considered the representative families of the bedrock at MPR No. 32.

\subsection{Density}

[25] Reported a density of 30.91 specimens $/ \mathrm{m}^{2}$ of Polyplacophora in three beaches of Acapulco, which is very similar to this study.

[21-24] reported as the most abundant species $C$. articulatus. [25,26,37] reported I. muscarius, C. retusa, C. lurida, C. albolineatus and $C$. articulatus as those with high density. This research coincides with the above mentioned authors that the species I. muscarius, C. articulatus, $C$. albolineatus and $C$. lurida as those with high population density and therefore are considered to be as the representative species of Polyplacophora at the intertidal rocky substrate of the MPR No. 32.

The difference with other reports made to various sites in the state of Guerrero in terms of species richness and density representation of families is due to the substrate structural nature of the seven sites sampled, which together represent the different types of environments and a wide variety of habitats. Another element to consider is the method of collection used, since the area at the sampling unit was carefully checked, which was possible due to the size of the area sampled and the characteristics of easy accessibility of staff to the sites, further that most of the sites have middle or low wave intensity.

\subsection{Geographic Distribution}

[8] study on the distribution of chitons made in fieldwork and visits to formal collections and literature review, reported 23 species of Polyplacophora distributed in the Mexican Tropical Pacific coast, from which in this study 11 species in MPR No. 32 were found, which are: $I$. muscarius, S. limaciformis, C. elenensis, C. retusa, $C$. lurida, C. unilineata, C. hanselmani, C. articulatus, $C$. albolineatus, T. forbesii forbesii and $L$. beanii. The species reported by these authors and were not found in the region are: Leptochiton (Leptochiton) alveolus (Lovén 1846, ex M. Sars); Leptochiton belknapi Dall, 1878; Leptochiton incorgruuns Dall, 1908; Stenoplax (Stenoplax) boogii (Haddon, 1886), L. clathrata; Lepidozona (Lepidozona) formosa Ferreira, 1974; L. rothi; Lepidozona (Lepidozona) skoglundi (Ferreira, 1986); Callistochiton expressus (Carpenter, 1865); Callistochiton colimensis (Smith, 1961), C. angelica and Acanthochitona stokesii Dall, 1919; the latter was reported by [35] as widely distributed species in the Mexican Pacific.

Species that found by [26] in the MPR No. 32 were $S$. rugulata, L. serrata, L. hartwegii, L. salvadorensis, Lepidochitona sp. 1, Lepidochitona sp. 2 and A. arragonites.
This study reports for the first time L. flectens for the Mexican Tropical Pacific and S. mariposa for MPR No. 32.

[24] reported C. articulatus as widely dispersed on the coasts of Guerrero because it was found in nine beaches in the three coastal regions where his study was conducted. This study further the chitons $C$. articulatus was found to be widespread in the MPR No. 32, and three species more: I. muscarius, C. unilineata and $C$. albolineatus.

\subsection{Hierarchical Status}

With respect to the degree of species occurrence (hierarchical position), [26] reported that Polyplacophora represented $47.05 \%$ of the dominant species. Our findings are in agreement with it on the percentage of dominant species. It also agrees that I. muscarius, C. retusa, $C$. lurida, C. articulatus, C. albolineatus and $T$. forbesii forbesii, were the dominant species. In this investigation, S. limaciformis, C. elenensis, C. elenensis and C. unilineata also classified as dominant.

The set of dominant species were considered as representative of the community of rocky intertidal Polyplacophora MPR No. 32.

By the number of Polyplacophora species considered as representative, we believe that these organisms are well adapted to environmental conditions of the rocky intertidal, which is reflected in their design of its body (flat, oval, articulated sections, belt, and large muscular foot) is quite efficient to move and withstand the extreme conditions of this environment.

\subsection{Size Structures}

Information on the size structure of $C$. articulatus as commercially important species was mentioned by $[3,4$, 38,39]. Regarding to size structure for other chiton species, [38] reports that, no biometric information was found for other than $C$. articulatus. On size structure on the community, reports by [26,37] mentioned $C$. articulatus and $T$. forbesii forbesii with greater size. The present study is consistent with the reports above mentioned. These relationships enable biometric estimates such as condition factor and growth rate for any individual, and enable the estimations of different coefficients, which can then be compared to others obtained in the future.

\subsection{Diversity Index}

$[25,37]$ reported high diversity indices similar to those estimated in this study. The diversity and equity index here reported indicate, the MPR No. 32 has a highly diversified community. 


\section{ACKNOWLEDGEMENTS}

This work was partly funded by CONACYT (Consejo Nacional de Ciencia y Tegnología-National Council of Science and Technology) and the state government of Guerrero through the research project No. 91624 Ecological study of the Acapulco Bay FOMIX 2008-C01 and the research project No. 91724 Diversity and abundance of marine cockroach off the coast of Guerrero state Fomix 2008-C01.

\section{REFERENCES}

[1] Arriaga, L., Vázquez, D.E., González, J.C., Jiménez, R., Muñoz, E. and Aguilar V. (1998) Regiones prioritarias marinas de México. Comisión Nacional para el Conocimiento y Uso de la Biodiversidad, México City.

[2] Reyes, G.A. (1999) Sistemática de los quitones (Mollusca: Polyplacophora). De la colección de moluscos del instituto de Biología de la UNAM. Tesis de Licenciatura en Biología, Faculta de Ciencias Biológicas, Universidad Nacional Autónoma de México, México City.

[3] Rojas, H.A.A. (1988) Análisis biológico-pesquero de la cucaracha de mar (Chiton articulatus Sowerby, 1832) de Acapulco, Gro Mexico Memorias del IX congreso nacional de zoología, Villahermosa, Tabasco. Tomo 1. Universidad Juárez Autónoma de Tabasco y Sociedad Mexicana de Zoología, México City.

[4] Holguín, Q.O.E. and Michel-Morfín, J.E. (2002) Distribution, density and length-weight relationship of Chiton articulatus Sowerby 1832 (Mollusca-Polyplacophora) on Isla Socorro Revillagigedo Archipelago Mexico. Journal of Shellfish Research, 21, 239-241.

[5] Galeana-Rebolledo, L., Suástegui-Herrera, M.A., TórralesGutiérrez, G., Millán-Román, C.A., García-Ibáñez, S., Flores-Garza, R., Flores-Rodríguez, P. and Arena-Salvador, D.G. (2007) Estudio de la población del Chiton articulatus Sowerby, 1832 en Playa Ventura, Copala, Guerrero, como un recurso de importancia comercial. In: Ríos-Jara, M., Esqueda-González, C. and Galván-Villas, C.M., Eds., Estudios sobre la malacología y conquiliología en México, Universidad de Guadalajara, Guadalajara, 185-187.

[6] Flores-Campaña, L.M., Ortiz-Arellano, M.A., ArzolaGonzález, J.F., González-Medina, F.L., Cortez-Acosta, E. and Rodríguez-García, D. (2007) Los quitones de las Islas de la costa de de Sinaloa México. In: Ríos-Jara, M., Esqueda-González, C. and Galván-Villas, C.M., Eds., Estudios sobre la malacología y conquiliología en México, Universidad de Guadalajara, Guadalajara, 43-45.

[7] Flores-Garza, R., García-Ibáñez, S., Flores-Rodríguez, P., Torreblanca-Ramírez, C., Galeana-Rebolledo, L., ValdésGonzález, A., Suástegui-Zárate, A. and Violante- González, V. (2012) Commercially important marine mollusks for human consumption in Acapulco México. Natural Resources, 3, 11-17. doi:10.4236/nr.2012.31003

[8] Reyes-Gómez, A. and Salcedo-Vargas, M.A. (2002) The recent Mexican chiton (Mollusca: Polyplacophora) species. The Festivus, 34, 17-27.

[9] Keen, A.M. (1971) Sea shells of tropical West America.
Stanford University Press, California.

[10] Kaas, P. and Van Belle, R.A. (1985) Monograph of living chitons (Mollusca: Polyplacophora). Suborder Ischnochitonina. Ischnochitonidae. Schizoplacinae, Callochitoninae and Lepidochitoninae, Leiden.

[11] Kaas, P. and Van Belle, R.A. (1990) Monograph of living chitons (Mollusca: Polyplacophora). Suborder Ischnochitonina: Ischnochitonidae: Ischnochitoninae. E. J. Brill/ W. Backhuys, Leiden.

[12] Kaas, P. and Van Belle, R.A. (1994) Monograph of living chitons (Mollusca: Polyplacophora). Suborder Ischnochitonina: Ischnochitonidae: Ischnochitoninae (concluded); Callistoplacinae; Mopaliidae. E. J. Brill/W. Backhuys, Leiden.

[13] Román, C.R., Cruz, A.F.M. and Ibáñez, A.A.L. (1991) Observaciones ecológicas de los moluscos de la zona intermareal rocosa de la bahía de Chamela Jalisco México. Anales del Instituto de Biología Universidad Nacional Autónoma de México serie Zoología, 62, 17-32.

[14] Villarroel, M.M., Magaña, M.A., Gómez, C.B., Lucio, P.J. and Sánchez, S.J. (2000) Diversidad de moluscos en el litoral rocoso de Michoacán México. Mexicoa, 2, 54-63.

[15] Rodríguez, U.M.C. (2007) Guía Ilustrada para la identificación de moluscos intermareales y de arrecifes de playa Mora Tenacatita Jalisco. Tesis de Ingeniero en Recursos Naturales y Agropecuarios, Universidad de Guadalajara, Centro Universitario de la Costa del Sur, Autlán de Navarro.

[16] García, C.I. and Álvarez, M. (2007) Comunidades de quitones (Mollusca: Polyplacophora) de la bahía de la Paz California Sur México. Revista de Biología Tropical, 55, 177-182.

[17] Bautista-Moreno, L.M. and Lechuga-Medina, A. (2007) Colecciones biológicas de moluscos de los Archipiélagos de Revillagigedo Col. e Islas Marías Nay. México. In: Ríos-Jara, E., Esqueda-González, M.C. and Galván-Villa, C.M., Eds., Estudios sobre la malacología y conquiliología en México, Universidad de Guadalajara, México City, 101-103.

[18] Zamorano, P., Barrientos-Luján, N.A. and Ramírez-Luna, S. (2008) Malacofauna del infralitoral rocoso de Agua Blanca Santa Elena Cozoaltepec Oaxaca. Ciencia y Mar, 12, 19-33.

[19] Ortiz-Arellano, M.A. and Flores-Campaña, L.M. (2008) Catálogo descriptivo e ilustrado de los moluscos de la zona intermareal de las islas de Navachiste Sinaloa México. Universidad Autónoma de Sinaloa y Gobierno del Estado de Sinaloa-Consejo Nacional de Ciencias y Tecnología, Culiacán.

[20] Reyes-Gómez, A., Barrientos-Lujan, N., Medina-Bautista, J. and Ramírez-Luna, S. (2010) Chitons from the coralline area of Oaxaca México (Polyplacophora). Bollettino Malacologico, 46, 111-125.

[21] Villalpando, C.E. (1986) Diversidad y zonación de moluscos de superficie rocosa, Isla Roqueta, Acapulco, Guerrero. Tesis de Licenciatura, Universidad Nacional Autónoma de México, México City.

[22] Salcedo, S., Green, G., Gamboa, A. and Gómez, P. (1988) 
Inventario de macroalgas y macroinvertebrados bénticos, presentes en áreas rocosas de la región de Zihuatanejo Guerrero México. Anales del Instituto de Ciencias del Mar y Limnología Universidad Nacional Autónoma de México, 15, 73-96.

[23] García, J.A. (1994) Fauna malacológica de acompañamiento del caracol Purpura pansa (Gould1853) en la zona mesolitoral de la isla Roqueta, Acapulco, Guerrero, México. Tesis de Licenciatura en Ecología Marina, Universidad Autónoma de Guerrero. Acapulco.

[24] Flores, R.P. (2004) Estructura de la comunidad de moluscos del mesolitoral superior en las playas de facie rocosa del estado de Guerrero, México. Tesis doctoral en Ciencias Biológicas con especialidad en Ecología, Universidad Autónoma de Nuevo León, San Nicolás de los Garza.

[25] Flores-Garza, R., Galeana-Rebolledo, L., García-Ibáñez, S., Flores-Rodríguez, P. and Torreblanca-Ramírez, C. (2010) Diversidad y estructura de la comunidad de Polyplacophora en el mesolitoral rocoso Acapulco Guerrero México. In: Rangel, L.J., Gamboa, J., Arriaga, S.L. and Contreras, W.M., Eds., Perspectiva en malacología Mexicana, Universidad Juárez Autónoma de Tabasco, Villahermosa, 141-152.

[26] Flores-Garza, R., Torreblanca-Ramírez, C., Flores-Rodríguez, P., García-Ibáñez, S., Galeana-Rebolledo, L., Valdés-González, A. and Rojas-Herrera, A.A. (2011) Mollusca community from a rocky intertidal zone in Acapulco México. Biodiversity, 12, 144-153. doi:10.1080/14888386.2011.625520

[27] Mottana, A., Crespi, R. and Liborio, G. (1980) Guía de minerales y rocas, segunda edición. Grijalbo, Barcelona.

[28] Sirenko, B. (2006) New outlook on the system of chitons (Mollusca: Polyplacophora). Venus, 65, 27-49.

[29] Sokal, R.R. and Rohlf, F.J. (1969) Biometry. The principles and practices of statisties in biological research. 2nd Edition, W.H. Freeman, San Francisco.

[30] Ferreira, J.A. (1983) The chiton fauna of the Revilla- gigedo Archipelago Mexico. The Veliger, 25, 307-322.

[31] Holguín, Q.O.E., Wright, L.H. and Félix, P.E.F. (2000) Moluscos intermareales y de fondos someros de la bahía de Loreto B. C. S. México. Oceánides, 15, 91-115.

[32] Flores-Rodríguez, P., Flores-Garza, R., García-Ibáñez, S. and Valdés-González, A. (2003) Riqueza y diversidad de la malacofauna del mesolitoral rocoso de la Isla la Roqueta Acapulco Guerrero México. Ciencia Revista de Investigación Científica, 11, 5-14.

[33] Valdez-González, A., Flores-Rodríguez, P., Flores-Garza, R. and García-Ibáñez, S. (2004) Molluscan communities of rocky intertidal zone at two sites with different wave action on Isla la Roqueta, Acapulco, Guerrero, México. The Journal of Shellfish Research, 23, 875-880.

[34] Skoglund, C. (2001) Panamic province molluscan literature additions and changes from 1971 through 2000. I. Bivalvia and II Polyplacophora. The Festivus, 32, 139.

[35] Reyes-Gómez, A. (2004) Chitons in mexican waters. Bolletino Malacologico, 5, 69-82.

[36] Martínez-Morales, M.A. (2004) Nuevos registros de aves en el bosque de mesófilo de montaña del noreste de Hidalgo México. Huitzil, 5, 12-19.

[37] Torreblanca, R.C. (2010) Análisis de la diversidad y estructura de la comunidad de moluscos del mesolitoral rocoso de Acapulco, Gro. Tesis de Licenciatura de Ecología Marina, Unidad Académica de Ecología Marina Universidad Autónoma de Guerrero, Acapulco, Guerrero.

[38] García, I.S., Flores, G.R., Rodríguez, F.P. and Arana, S.D.G. (2012) Los quitones o cucarachas de mar (Mollusca: Polyplacophora): Una perspectiva de su diversidad biológica y manejo sostenible. Fomix Guerrero, 1, 17-22.

[39] Flores-Campaña, L.M., González-Montoya, M.A., OrtizArellano, M.A. and Arzola-González, J.F. (2007) Estructura de Chiton articulatus en las Islas Pájaros y Venados de la bahía de Mazatlán Sinaloa México. Revista Mexicana de Biodiversidad, 78, 23-71. 